\title{
Concentration of Partial VFA and Methane Production of Beef Cattle Rument Fluid which Red Dragon Fruit Skin (Hylocereus costaricensis) and Guava Leaf (Psidium guajava L.) in Ammoniated Rice Straw Based Ration
}

\author{
Aziz Nur Rahmat*, Wardhana Suryapratama and Fransisca Maria Suhartati \\ Faculty of Animal Science, Jenderal Soedirman University \\ Jl. Dr. Soeparno, Karang Wangkal, North Purwokerto 53122 \\ *Corresponding author email: azizrahmat62@yahoo.com
}

\begin{abstract}
The research aimed to examine the effect of red dragon fruit skin and guava leaves supplemented into beef cattle feed on the concentration of partial VFA and methane gas production. The in vitro study was conducted in a completely randomized design (CRD) with 3 treatments, namely P0: $50 \%$ concentrate $+50 \%$ ammoniated straw (Control), P1: $50 \%$ concentrate $+50 \%$ ammoniated straw $+5 \%$ red dragon fruit skin flour, and P2: $50 \%$ concentrate $+50 \%$ ammonia straw $+5 \%$ red dragon fruit skin flour $+2.5 \%$ guava leaf flour. The concentrate consisted of 2 parts of rice bran and 1 part of coconut meal. The ratio of concentrat and ammoniated rice straw was 50:50. Each treatment was repeated 6 times. The results showed that the concentration of acetic acid, butyrate and methane gas decreased while the concentration of propionate increased with the addition of red dragon fruit and guava leaves. The research concluded that the addition of 5 $\%$ red dragon fruit skin flour combined with $2.5 \%$ guava leaves flour in beef cattle feed could further reduce the concentration of acetic acid, butyric acid and the production of methane gas, but increase the concentration of propionic acid. It is suggested that defaunated agents of red dragon fruit skin and guava leaves could reduce the production of methane gas in the rumen of beef cattle.
\end{abstract}

Keywords: red dragon fruit skin, guava leaves, partial VFA concentration, methane gas production

Abstrak. Penelitian ini bertujuan untuk mengetahui pengaruh pemberian kulit buah naga merah dan daun jambu biji ke dalam pakan sapi potong terhadap konsentrasi VFA parsial dan produksi gas metan. Penelitian in vitro dilakukan dalam Rancangan Acak Lengkap (RAL) dengan 3 perlakuan yaitu PO: konsentrat $50 \%+$ jerami amoniasi 50\% (Kontrol), P1: konsentrat 50\% + jerami amoniasi 50\% + tepung kulit buah naga merah $5 \%$, dan P2: konsentrat $50 \%+$ jerami amonia $50 \%+$ tepung kulit buah naga merah $5 \%+2,5 \%$ tepung daun jambu biji. Konsentrat terdiri dari 2 bagian dedak padi dan 1 bagian bungkil kelapa. Rasio Konsentrat dan jerami padi amoniasi adalah 50:50. Setiap perlakuan diulang sebanyak 6 kali. Hasil penelitian menunjukkan bahwa konsentrasi asam asetat, butirat dan gas metan mengalami penurunan, sedangkan konsentrasi propionat meningkat dengan penambahan tepung kulit buah naga merah dan tepung daun jambu biji. Hasil penelitian menyimpulkan bahwa penambahan $5 \%$ tepung kulit buah naga merah yang dikombinasikan dengan $2,5 \%$ tepung daun jambu biji pada pakan sapi potong dapat menurunkan konsentrasi asam asetat, asam butirat dan produksi gas metan, tetapi meningkatkan konsentrasi asam propionat. Agen defaunasi kulit buah naga merah dan daun jambu biji dapat menurunkan produksi gas metan dalam rumen sapi potong.

Kata kunci: kulit buah naga merah, daun jambu biji, konsentrasi VFA parsial, produksi gas metan

\section{Introduction}

Beef cattle is one of the meat suppliers with potential development in Indonesia. Optimizing meat production in beef cattle is made possible by improving various aspects, namely genetics, animal health, environment, and feed. The productivity level of beef cattle in Indonesia, especially those bred by traditional breeders is still relatively low. The contributing factors to this include the provision of low-quality feed (Suprapto, 2013). Low-quality feed will cause digestive disturbances in the rumen because protozoa will prey on bacteria (Kurniawati 2009). It is detrimental because rumen bacteria are the primary source of microbial protein for host animals. Meanwhile, protozoa, being the predatory microorganisms, will remain in the rumen and experience lysis without undergoing 
digestive processes in the subsequent digestive tract.

The number of protozoa must be pressed so that the number of bacteria does not go down, to produce microbial proteins that can be utilized by host animals. In addition, protozoa are symbiotic with methanogenic bacteria that produce methane gas, rendering livestock lose a lot of energy and affects global warming. The efforts to reduce total protozoa include using dragon fruit skin and guava leaves as a defaunation agent.

Red dragon fruit skin phytochemical (Hylocereus costaricensis) contains alkaloids, steroids, triterpenoids, and flavonoids (Saneto, 2008). According to Kurniawati (2006), the chemical composition in guava leaves is $9-12 \%$ tannins, saponins, essential oils, malic acid, ursolic acid, psydiolic acid, kratogolic acid, oleanolic acid, guajavarin acid, and vitamins. Red dragon fruit skin and guava leaves are agricultural wastes containing saponins and tannins that can be a defaunation agent. The abundant availability of guava plants (Psidium guajava L) in Indonesia includes the 10,800-ha harvested area of guava plants with a total production value of 212,260 tons. Java Island is the largest center for guava cultivation in Indonesia (BPS, 2016), whereas red dragon fruit skin weighs $30-35 \%$ of fruit weight. Research using red dragon fruit skin has been carried out with a level of $4 \%$, but only able to reduce the number of live protozoa by $4 \%$ and methane gas by $9 \%$ (Susiani, 2018). At the same time, research on guava leaves as a defaunation agent has not been done much. Therefore, the combination of red dragon fruit skin and guava leaves could reduce the total living protozoa and methane gas production. Based on this description, it is necessary to research to determine the effect of giving red dragon fruit skin and guava leaves on ammoniated rice straw-based feed to rumen fermentation products.

\section{Materials and Methods}

The research was an in vitro experimental method (Tilley and Terry, 1963 modified by Sutardi, 1979). The experiment used rumen fluid from 3 male beef cattle aged $\geq$ two years, taken from Bantarwuni abattoir, Kembaran subdistrict, immediately after the cows were slaughtered. Other materials were guava leaf flour, red dragon fruit skin flour, and ammoniated rice straw, and concentrates (66.67\% rice brand and $33.33 \%$ coconut meal). The ratio of concentrate to ammonia rice straw was 50:50. Table 1 shows the nutrient content of feed ingredients, and Table 2 illustrates the ration composition.

The research design used was Completely Randomized Design (CRD), 3 types of treatment namely P0: $50 \%$ concentrate $+50 \%$ ammoniated straw (Control); P1: $50 \%$ concentrate $+50 \%$ ammoniated straw $+5 \%$ red dragon fruit skin flour; P2: $50 \%$ concentrate $+50 \%$ ammoniated straw $+5 \%$ red dragon fruit skin flour $+2.5 \%$ guava leaf flour. Each treatment was repeated six times, so there were 18 treatment units.

Table 1. The nutrient content of the feed ingredients for the treatment ration

\begin{tabular}{lllllll}
\hline Bahan Pakan & $\begin{array}{l}\text { Dry Matter } \\
(\%)\end{array}$ & $\begin{array}{l}\text { Ash } \\
(\%)\end{array}$ & $\begin{array}{l}\text { Crude } \\
\text { Protein } \\
(\%)\end{array}$ & $\begin{array}{l}\text { Crude Fat } \\
(\%)\end{array}$ & $\begin{array}{l}\text { Crude } \\
\text { Fiber } \\
(\%)\end{array}$ & $\begin{array}{l}\text { Nitrogen } \\
\text { Free Extract } \\
(\%)\end{array}$ \\
\hline Concentrate & 89.63 & 6.38 & 14.10 & 11.11 & 19.98 & 48.43 \\
Rice bran & 89.66 & 6.85 & 12.62 & 11.25 & 19.54 & 49.72 \\
Coconut meal & 89.58 & 5.45 & 17.05 & 10.82 & 20.86 & 45.83 \\
Ammoniated rice straw & 93.16 & 20.65 & 5.23 & 2.03 & 43.06 & 29.03 \\
Red dragon fruit skin & 88.61 & 14.77 & 9.68 & 0.46 & 25.61 & 49.48 \\
Guava leaf & 90.37 & 4.76 & 13.26 & 1.19 & 34.27 & 46.52 \\
\hline
\end{tabular}


Table 2. The arrangement of ration treatment

\begin{tabular}{lccc}
\hline \multicolumn{1}{c}{ Feed Ingredients } & P1 & P2 & P3 \\
\cline { 2 - 4 } & (\%) & (\%) & (\%) \\
\hline Ammoniated rice straw & 50 & 50 & 50 \\
Concentrate & 50 & 50 & 50 \\
Red dragon fruit skin flour & - & 5 & 2.5 \\
Guava leaf flour & - & - & 107.5 \\
\hline Total & 100 & 105 & 98.09 \\
\hline Dry Matter (\%) & 94.40 & 95.83 & 14.37 \\
Ash (\%BK) & 13.52 & 14.26 & 10.48 \\
Crude Protein (\%BK) & 9.66 & 10.15 & 6.62 \\
Crude Fat (\%BK) & 6.57 & 6.59 & 33.66 \\
Crude Fiber (\%BK) & 31.52 & 32.80 & 42.37 \\
Nitrogen Free Extract (\%BK) & 38.73 & 41.21 & \\
\hline Description: P0: 50\% Concentrate + 50\% Ammonia Straw (Control) P1: $50 \%$ Concentrate $+50 \%$ Ammonia straw +
\end{tabular}

Description: P0: 50\% Concentrate + 50\% Ammonia Straw (Control) P1: 50\% Concentrate + 50\% Ammonia straw + 5\% Red dragon fruit skin flour P2: 50\% Concentrate $+50 \%$ Ammonia straw $+5 \%$ Red dragon fruit skin flour $+2.5 \%$ Guava leaf flour

The measured variables are 1). The partial VFA concentrations followed the Georing and van Soest methods (1970), 2). Methane gas production $(\mathrm{CH} 4)$ was calculated using the formula Orskov and Ryle (1990). The research was conducted at the Laboratory of Animal Nutrition and Feed Sciences (INMT), Faculty of Animal Husbandry, Jenderal Soedirman University, Purwokerto. The analysis of partial VFA concentrations was accomplished at the TPHP Faculty of Gadjah Mada University, Yogyakarta.

\section{Results and Discussion}

Partial concentration of Volatile Fatty Acids (VFA)

VFA components in rumen fluid are acetic acid, propionic acid, and butyric acid. Table 3 shows the result of the in vitro study of the supplementation of red dragon fruit skin and guava leaves in beef cattle feed on Volatile Fatty Acids (VFA) concentration.

The average partial VFA concentrations of this study were higher than the report by Wahyuni (2014) using saponin supplementation, tannin, and tannin saponin combination, namely 72.53-78.83 mM acetic acid, 13.30-17.19 mM propionic acid, and 4.8211.49 butyric acid. According to Suwandyastuti
(2007), the difference in partial VFA concentration is due to variation in ration composition. The main components of VFA are acetic acid and propionic acid as well as a small amount of butyric acid and other VFA components, such as formic acid, isobutyrate, valerate, isovalerate, and isocaproate (Czerkawski, 1986; Syamsi et al., 2019). The statement agreed with the average results of partial VFA studies showing that the highest average is acetic acid and propionic acid, and the lowest is butyric acid. Suhartanto et al. (2014) stated that acetic acid content in rumen fluid is affected by feed contents and fiber feed. The average acetic acid ranged from $61.36 \pm$ 5.27 to $90.31 \pm 4.36 \mathrm{mM}$ (Table 1 ). These results were higher than those of González et al. (2014), that dairy cows feeding on green forage produced at least $32 \mathrm{mM}$ acetate of rumen fluid or reached $65 \%$ of the total VFA to meet their body needs.

The results of the variance analysis showed that red dragon fruit skin and guava leaf supplements were highly significant $(P<0.01)$ on the concentration of ruminal acetic acid of beef cattle. The contrast test showed that the concentration of rumen liquid acetic acid that received control feed $(90.31 \pm 4.36 \mathrm{mM})$ was higher than that receiving additional red dragon fruit skin and guava leaves $(63.63 \pm 7.78 \mathrm{mM})$. 
Table 3. Average volatile fatty acids (VFA) concentrations of partial rumen fluid of beef cattle supplemented with red dragon fruit skin and guava leaves

\begin{tabular}{lccc}
\hline & \multicolumn{3}{c}{ VFA concentration } \\
\cline { 2 - 4 } & VFA & \multicolumn{3}{c}{ P1 } \\
\cline { 2 - 4 } & $90.31^{\mathrm{c}} \pm 4.36$ & $65.90^{\mathrm{b}} \pm 10.29$ & $61.36^{\mathrm{a}} \pm 5.27$ \\
\hline Acetate & $28.11^{\mathrm{a}} \pm 4.09$ & $29.55^{\mathrm{b}} \pm 5.58$ & $37.63^{\mathrm{c}} \pm 9.47$ \\
Propionat & $13.56^{\mathrm{a}} \pm 2.32$ & $12.76^{\mathrm{a}} \pm 3.33$ & $12.02^{\mathrm{a}} \pm 2.66$ \\
Butyric & $44.13^{\mathrm{c}} \pm 2.46$ & $31.93^{\mathrm{b}} \pm 5.03$ & $28.04^{\mathrm{a}} \pm 3.89$ \\
Methane Gas & &
\end{tabular}

Description: P0: 50\% Concentrate + 50\% Ammonia Straw (Control) P1: 50\% Concentrate $+50 \%$ Ammonia straw $+5 \%$ Red dragon fruit skin flour P2: 50\% Concentrate $+50 \%$ Ammonia straw $+5 \%$ Red dragon fruit skin flour $+2.5 \%$ Guava leaf flour.

The concentration of acetic acid in rumen fluid treated with $5 \%$ red dragon fruit skin $(65.90 \pm$ $10.29 \mathrm{mM}$ ) was higher than that with $5 \%$ red dragon fruit skin and $2.5 \%$ guava leaves $(61.36$ $\pm 5.27 \mathrm{mM}$ ). Therefore, $2.5 \%$ guava leaves incorporated to feed containing $5 \%$ red dragon fruit skin could reduce the acetic acid concentration.

The acetic acid reduction (C2) in the treatment ration is due to the addition of defaunation agents that are red dragon fruit skin and guava leaves on (P1) and (P2) treatments. The defaunation agent is saponin that can form bonds with sterols contained in the walls of protozoa cells. It increased cell wall permeability, and, eventually, fluid from outside of the cell will enter the protozoa cells. The entry of fluid from outside of the cell ruptures the cell wall, so the protozoa perish or lysis. However, the decrease in the number of protozoa in the rumen can decrease ruminal $\mathrm{pH}$. It confirms Vieira et al. (1984) that protozoa are essential for maintaining $\mathrm{pH}$. Rumen $\mathrm{pH}$ decreases due to the absence of protozoa that swallow starch, so the starch is converted by bacteria to lactic acid that diminishes rumen $\mathrm{pH}$ (Suhartanto et al., 2014). In the presence of protozoa, some bacteria are consumed, and the $\mathrm{pH}$ does not drop dramatically. A low $\mathrm{pH}$ will reduce the bacteria-degrading crude fiber (cellulolytic) in the rumen, so acetic acid(a fermentation product) decreases. In this research, the concentration of acetic acid decreased in each treatment. Widiawati (2007) stated that the soluble feed fraction is fermented quickly so that the rumen $\mathrm{pH}$ drops to below 6. This condition would inhibit the growth of acetic acid-producing bacteria.

Glucogenic is a propionic acid produced from the degradation of easily-digestible carbohydrates (NFE) in the rumen as glucose or glucose precursor for meat formation (Personal, 2015). On the other hand, acetic and butyric acids are lipogenic and can increase dairy cow milk fat (Thalib and Widiawati, 2008). The average yield of propionic acid at 28.11-37.63 $\mathrm{mM}$ (Table 1) saw an increase from each treatment, and it was higher than 3.56-6.76 $\mathrm{mM}$ by Dioksa et al. (2015) using fermented rations.

Variance analysis results showed that the treatment of red dragon fruit skin flour and guava leaf flour supplementation had a significant effect $(P<0.05)$ on the propionic acid concentration in beef rumen fluid. The orthogonal contrast test results indicated that the concentration of rumen liquid propionic acid that received control feed $(28.11 \pm 4.09$ $\mathrm{mM}$ ) was lower than that which received an additional red dragon fruit skin and guava leaves (33.59 $\pm 7.52 \mathrm{mM}$ ). The concentration of propionic acid in rumen fluid that was treated with the addition of $5 \%$ red dragon fruit skin flour (P1) $(29.55 \pm 5.58 \mathrm{mM})$ was lower than that which received an additional $5 \%$ red dragon fruit skin flour, and $2.5 \%$ guava leaves flour $(37.63 \pm 9.47 \mathrm{mM})$. Furthermore, the orthogonal contrast test results denoted that $2.5 \%$ of guava leaves flour incorporated to feed 
containing $5 \%$ red dragon fruit skin flour could increase the concentration of propionic acid.

The increase in propionic acid occurs because of red dragon fruit skin and guava leaves flour as a defaunation agent. As previously described, saponins could make protozoa perish or lysis by forming complex bonds with sterols on the surface of the protozoa membrane. Therefore, it disrupts the development of protozoa, ruptures the membrane, and makes the cells lysis and protozoa perish. Protozoa are more susceptible to saponins than bacteria because the membrane walls of protozoa contain cholesterol whereas bacteria are peptide bonds with glycerol (peptidoglycan). Bacteria do not have sterols that can bind to saponins. Besides, bacteria can metabolize the anti protozoa factor by removing carbohydrate chains from saponins (Cheeke, 2000). It could increase the number of bacteria in the rumen so that the propionic acid-producing bacteria increases. Wina (2005) stated that the main effect of giving saponin to feed on rumen fermentation is a change in the pattern of short-chain fatty acids that can increase the proportion of propionic acid. According to Widiawati (2007), the soluble feed fraction will be fermented rapidly so that the rumen $\mathrm{pH}$ drops below 6 . This condition will stimulate the growth of propionic acid-producing bacteria.

Butyric acid is a ketogenic fatty acid that always has a lower value than acetic acid and propionic acid (Syamsi et al., 2018). The average results of butyric acid researches were in the range of $12.02 \pm 2.66$ to $13.56 \pm 2.32 \mathrm{mM}$ rumen fluid (Table 1). This result was lower than that of Susiani (2018) on 4\% dragon fruit skin as a treatment. The different results are due to the variation of feeds and conditions since different ruminal microbes' composition produces different results of butyric acid (Leek, 1993).

The variance analysis results indicated that the treatment of red dragon fruit skin and guava leaves flour significantly affected ( $P$ $<0.05$ ) the concentration of butyric acid in beef rumen fluid. The orthogonal contrast test results revealed that the rumen fluid butyric acid concentrations that received control feed (13.56 $\pm 2.32 \mathrm{mM})$ were higher than those which received the addition of red dragon fruit skin and guava leaves $(12,391 \pm 2.99 \mathrm{mM})$. Butyric acid concentrations fed with treatment with the addition of red dragon fruit skin $5 \%$ (P1) (12.76 $\pm 3.33 \mathrm{mM}$ ) were higher than those receiving $5 \%$ red dragon fruit skin and guava leaves $2.5 \%$ (12.02 $\pm 2.66 \mathrm{mM})$. Moreover, the orthogonal contrast test showed that the addition of $2.5 \%$ guava leaf to feed containing 5 $\%$ red dragon fruit skin could reduce the butyric acid concentration.

The formation of butyric acid in the rumen is relevant to the formation of acetic acid, so the concentration of acetic acid increases with the butyric acid (Uhi, 2006). According to Mitsumori and Sun (2008), the acetic and butyric acids are both derived from acetyl coenzyme A (AC-CoA), but the acetic formation is faster than butyric. Leek (1993) explains that the formation of butyrate starts from AC-CoA conversion to acetone acetate, to $\beta$ hydroxybutyrate, and finally to butyric; meanwhile, acetic is directly produced from AC-CoA. Therefore, butyric concentrations in this research are much lower than those of acetic.

\section{Methane gas production}

The average production of methane gas in rumen fluid of beef cattle supplemented with red dragon fruit skin and guava leaves flour in feeds tested in vitro ranged from 28.043-44.133 \pm 3.79 mM (Table 3). Similarly, Wahyuni (2014) on saponins, tannins, and tannin + saponins reported an average methane gas of 37.11 $40.02 \pm 3.55 \mathrm{mM}$. The production of methane gas in ruminants derives from the fermentation of the digestive system (methanogenesis). Methanogenesis can cause energy losses of up to $15 \%$ of the total chemical energy that is 
affected. The formation of methane gas in the rumen is through $\mathrm{CO}_{2}$ reduction by $\mathrm{H}_{2}$ catalyzed by enzymes produced by methanogenic bacteria (Thalib and Widiawati, 2008). Table 1 shows the difference in the production of methane gas from each treatment. The production of methane gas from each treatment has decreased.

The results of the variance analysis indicated that the treatment of red dragon fruit skin and guava leaves flour supplementation highly significantly affected $(P<0.01)$ the production of methane gas in the rumen. Orthogonal contrast test results showed that the production of rumen fluid methane gas that received control feed $(44.13 \pm 2.45 \mathrm{mM})$ was higher than that which received additional red dragon fruit skin and guava leaves flour $(29.99 \pm$ $4.45 \mathrm{mM})$. The production of rumen fluid methane gas treated with the addition of red dragon fruit skin flour 5\% (P1) (31.94 \pm 5.02 $\mathrm{mM}$ ) was higher than that which received an additional $5 \%$ red dragon fruit skin and guava leaves flour $2.5 \%$ (P2) ( 28,043 $\pm 3.89 \mathrm{mM})$. Orthogonal contrast test results also showed that the addition of $2.5 \%$ guava leaves flour to feed containing $5 \%$ red dragon fruit skin flour could reduce more methane gas production.

The decrease in methane gas production occurs because the number of rumen protozoa is reduced due to defaunation using red dragon fruit skin and guava leaves flour. Tannin compound is one of the defaunation agents for protozoa. Tannins in red dragon fruit skin and guava leaves flour are toxic to methanogenic bacteria, so decreasing the amount. According to Patra (2010), defaunation would decrease the production of methane gas by 30 to $45 \%$, and the process of methanogenesis occurs $37 \%$ of the endosymbiosis connection between protozoa and methanogenic bacteria. Hess et al. (2003) and Syamsi et al. (2018) explained that tannin composition from legumes is toxic to methanogenic bacteria, so the symbiotic displacement between methanogens and protozoa declines. It leads to little hydrogen to become methane.

Factors that affect the production of methane gas include the production of acetic acid (Martin et al., 2008). This research proved that the higher the concentration of acetic acid, the higher the methane gas production (Figure $3)$.

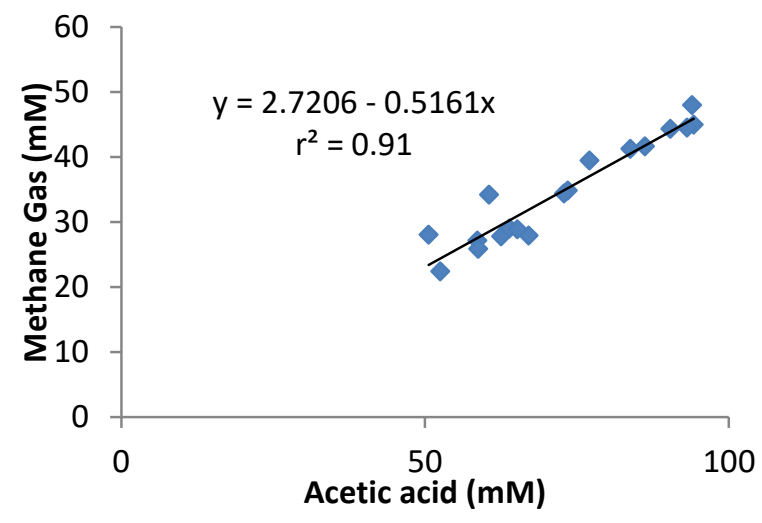

Figure 3. Relationship between methane gas and acetic acid

Based on Figure 3 , the higher the concentration of acetic acid, the higher the production of methane gas with the equation $y$ $=2.7206-0.5161 \mathrm{x}$ determinant coefficient 0.91 . These results occurred because of the similarity in the process of mole formation. According to Campbell and Reece (2005), the formation of one acetate mole acetate would produce two moles of $\mathrm{CO}_{2}$ and four moles of $\mathrm{H}_{2}$, while the formation of one butyric mole would produce two moles of $\mathrm{CO}_{2}$ and two moles of $\mathrm{H}_{2}$. The process of forming one mole of $\mathrm{CH}_{4}$ requires one mole of $\mathrm{CO}_{2}$ and four moles of $\mathrm{H}_{2}$. Therefore, the formation of acetic acid and high butyric acid will cause $\mathrm{CH}_{4}$ production to be high (Figure 3). Widiawati et al. (2010) stated that the high-production and concentration of $\mathrm{CH}_{4}$ indicate the total wasted feed energy that potentially reduces feed efficiency.

Methane gas could be reduced by increasing propionic acid. The results showed that the addition of red dragon fruit skin and guava leaves flour increased the concentration of 
propionic acid, thus decreasing the production of methane gas (Figure 4).

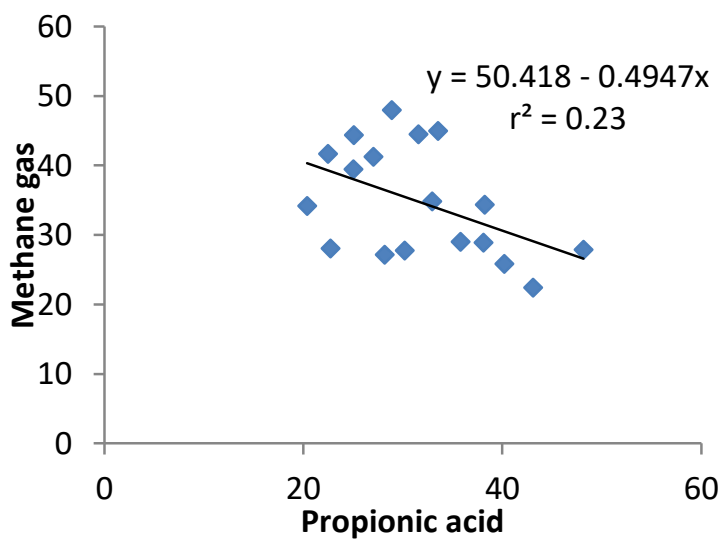

Figure 4. Relation between methane gas and propionic acid

Based on (Figure 4), it is clear that the higher the concentration of propionic acid, the production of methane gas decreases with the equation $y=50.418-0.4947 x$ the coefficient of determination 0.23 . These results occur because the process of forming propionic acid in the rumen requires more $\mathrm{H}_{2}$, whereas acetic acid and butyrate produce $\mathrm{H}_{2}$. Pribadi (2015) mentioned that propionic acid is used for the process of gluconeogenesis or is glucogenic. The formation of propionic acid in the rumen requires $\mathrm{H}_{2}$, so the low level of $\mathrm{H}_{2}$ may reduce methane gas production.

\section{Conclusions}

The addition of $5 \%$ red dragon fruit skin flour combined with $2.5 \%$ guava leaves flour in beef cattle feed can reduce more methane gas, acetic acid concentration, and butyric corrosive, but increase the concentrations of propionic acid. Treatment 2 is the best treatment to apply.

\section{References}

Campbell, N. and J. Reece. 2005. Animal Nutrition. 7th. edn. Pearson Educ. Inc. Publish.

Cheeke, P. R. 2000. Actual and Potential Applications of Yucca schidigera and Quillaja saponaria Saponins in Human and Animal Nutrition. In
Saponins in Food, Feedstuffs and Medicinal Plants. Springer, Dordrecht. Pp. 241-254.

Czerkawski, J.W. 1986. An Introduction to Rumen Studies. $1^{\text {st }}$ Ed. Pergamon Press. New York.

Dioksa, I. M. R., I. M. Mudita, A. A. P. P. Wibawa and I. W. Wirawan. 2015. Metabolit Rumen Sapi Bali yang Diberikan Ransum Terfermentasi dengan Inokulan yang Diproduksi dari Cairan Rumen Sapi Bali dan Rayap. J. Trop. Anim. Sci. 3(2): 386-404.

Goering, H. K. and P. J. Van Soest. 1970. Forage Fiber Analysis Agricultural Handbook No. 379. United States Departmen of Agricultural DC. Washington. Pp. 12-15.

González, A. R. C., M. E. B. Barraza, J. D. Viveros and A. C. Martínez. 2014. Rumen Microorganisms and Fermentation. Archivos de Medicina Veterinaria. 46(3): 349-361.

Kurniawati, A. 2006. Formulasi Gel Antioksidan Ekstrak Daun Jambu Biji dengan Menggunakan Aquapec HV-505. Jurnal Peternakan. 3(2): 17-25.

Leek, B. F. 1993. Digestion in The Ruminant Stomach. Dukes Physiology of Domestic Animals. 11th ed. M.J. Swenson and W.O. Reece, ed. Cornel University Press, Ithacha. Pp. 387-416.

Martin, G. B., D. Blache and J. Rodger. 2008. Nutritional and Environmental Effects on Reproduction in Small Ruminant. J. Reprod. Fertil. 16 (4): 491-501.

Mitsomori, M. and W. Sun. 2008. Control of Rumen Microbial Fermentation For Mitigrating Methane Emissions From the Rumen. Asian-Aust. J. Anim. Sci. 21(1): 144-154.

Pribadi, L. W. 2015. Promosi Pertumbuhan Sapi Bali pada Penggemukan Pakan Kurang dengan Addisi lonophore-Polyether dalam Ransum. Jurnal IImu dan Teknologi Peternakan Indonesia. 1(1): 71-77.

Saneto, B. 2008. Karakteristik Kulit Buah Naga Merah (Hylocereus polyrhizus). Agrika. 2(2): 143-149.

Suhartanto. 2014. Effect of Flour and Papaya Leaf Extract Addition to Feed on Gas Production, Digestibility and Energy Values In Vitro. J. Trop. Anim. Prod. 17(2): 32-40.

Susiani, G. R. 2018. Konsentrasi Volatile Fatty Acids Parsial Jumlah Protozoa dan Produksi Gas Metan Cairan Rumen Sapi Potong yang Diberi Pakan Jerami padi Amoniasi dan Disuplementasi Kulit Buah Naga. Thesis. Fakultas Peternakan Unsoed.

Sitoresmi, P. D., L. M. Yusiati and H. Hartadi. 2009. Pengaruh Penambahan Minyak Kelapa, Minyak Biji Bunga Matahari dan Minyak Kelapa Sawit Terhadap Penurunan Produksi Metan di dalam Rumen secara In Vitro. Buletin Peternakan. 33(2): 96-105.

Suwandyastuti, S. N. O. 2007. Produk Metabolisme Rumen pada Domba Jantan. J. Anim. Prod. 9(1): 9-13. 
Syamsi, A. N., T. Y. Astuti and P. Soediarto. 2018. Volatile Fatty Acids and Methane Profile of Dairy Cattle Ruminal Fluid was Gived Legumes in Ration Based on Synchronization Protein-Energy Index. Buletin Peternakan. 42(4): 283-289.

Syamsi, A. N., Waldi, L. and Widodo, H. S. 2019. Branched Chain Volatile Fatty Acids Profile of Rumen Fluids Suplemented by Different Meal Protein Sources and Protein-Energy Synchronization Index. In IOP Conference Series: Earth and Environmental Science (November.Vol. 372, No. 1, p. 012060). IOP Publishing.

Thalib, A. and Y. Widiyawati. 2008. Peningkatan Produksi dan Kualitas Susu dengan Emisi Gas Metan yang Rendah Melalui Pemberin RMK Sebagai Imbuhan pada Ransum Sapi Perah. JITP. 1(4): 33-42.

Uhi, H. T., A. Parakkasi and B. Haryanto. 2006. Pengaruh Suplemen Katalik Terhadap Karakteristik dan Populasi Mikroba Rumen Domba. Media Peternakan. 29(1): 20-26.

Viera, C., L. M. Yusiati and S. Alim. 2004. Effect of saponin as defaunating agent on in vitro ruminal fermentation of forage and concentrate. Jurnal Pengembangan Peternakan Tropis. 34(3): 231235.

Wahyono, T., W. T. Sasongko, M. Sholihah and M.
Ratnasari. 2017. Pengaruh penambahan tanin daun nangka (Artocarpus heterophyllus) terhadap nilai biologis daun kelor (Moringa oleifera) dan jerami kacang hijau (Vigna radiata) secara in vitro. Buletin Peternakan. 41 (1): 15 -25.

Wahyuni, I. M. D., A. Muktiani and M. Christianto. 2014. Penentuan Dosis Tanin dan Saponin untuk Defaunasi dan Peningkatan Fermentabilitas Pakan. JITP. 3 (3): 133-140.

Widiawati, Y., M. Winugroho and E. Teleni. 2007. Perbandingan Laju Degradasi Rumput Gajah dan Tanaman Leguminosa di dalam Rumen. Seminar Nasional Teknologi Peternakan dan Veteriner. Bogor.

Widyawati, S.D. 2009. Perbandingan Potensi Daun Ketepeng dan Minyak Ikan Lemuru Sebagai Agensia Reduksi Metan dalam Memperbaiki Kualitas Pakan Ternak Ruminansia. J. Sains Peternakan. 7 (1): 1 - 7.

Widyawati. 2010. Pengaruh Suplemen Katalik Terhadap Karakteristik dan Populasi Mikroba Rumen Pada Domba. J. Media Peternakan. 29 (1): $20-26$.

Wina, E., S. Muetzel and K. Becker. 2005. The Impact of Saponin-Countaining Plant Materials on Ruminant Production- A review. J. Agric. Food Chem. 53(21):8093-8105. 